The Demand for Tax Return Preparation Services

Author(s): Jeffrey A. Dubin, Michael J. Graetz, Michael A. Udell and Louis L. Wilde

Source: The Review of Economics and Statistics, Vol. 74, No. 1 (Feb., 1992), pp. 75-82

Published by: The MIT Press

Stable URL: http://www.jstor.org/stable/2109544

Accessed: 01-09-2017 22:10 UTC

JSTOR is a not-for-profit service that helps scholars, researchers, and students discover, use, and build upon a wide range of content in a trusted digital archive. We use information technology and tools to increase productivity and facilitate new forms of scholarship. For more information about JSTOR, please contact support@jstor.org.

Your use of the JSTOR archive indicates your acceptance of the Terms \& Conditions of Use, available at http://about.jstor.org/terms 


\title{
THE DEMAND FOR TAX RETURN PREPARATION SERVICES
}

\author{
Jeffrey A. Dubin, Michael J. Graetz, Michael A. Udell, and Louis L. Wilde*
}

\begin{abstract}
We analyze taxpayer choices of return preparation services. We distinguish between two types of nonpaid preparers, six types of paid third parties, and self-preparation. Among other things, we find significant differences in the factors which explain the demand for paid third parties who are and are not able to represent clients before the IRS. Among these factors are increases in IRS audit rates and the frequency of IRS penalties.
\end{abstract}

\section{Introduction}

$\mathrm{T}$ HE IRS has estimated that $44.2 \%$ of the individual returns filed in 1979 were self-prepared, and that these returns accounted for $22.8 \%$ of detected noncompliance. Returns prepared with third party assistance accounted for $55.8 \%$ of filings and $77.2 \%$ of the detected noncompliance. Among returns prepared with third party assistance, however, only $16.7 \%$ used what we call here a "tax practitioner" (public accountant or attorney) yet these returns accounted for $42.7 \%$ of underreported tax, $28.5 \%$ used other paid preparers accounting for $30.8 \%$ of underreported tax, and the remaining $10.6 \%$ used nonpaid assistance accounting for $3.7 \%$ of underreported tax. ${ }^{1}$ A detailed breakdown of the distribution of preparation modes for 1979 and the associated proportions of tax noncompliance are reported in table 1.

Economic theory has only recently focused on the demand for third party assistance and its role

Received for publication July 23, 1990 . Revision accepted for publication April 2, 1991.

* California Institute of Technology, Yale Law School, California Institute of Technology, and California Institute of Technology, respectively.

Professor Graetz thanks the National Science Foundation for research support (Grant No. SES-870443) as do Professors Dubin and Wilde (Grant No. SES-8701027). Professor Graetz is currently serving as Deputy Assistant Secretary (Tax Policy) of the Treasury. This article was written before Professor Graetz assumed that office and does not necessarily reflect the views of the Treasury Department. We acknowledge the very helpful comments of an anonymous referee.

${ }^{1}$ CPAs and attorneys are automatically able to represent clients before the IRS. Other paid preparers may provide these services only after passing a written exam sponsored by the IRS, and fulfilling certain continuing education requirements. Because most public accountants meet these requirements, we include them in the tax practitioner category. in tax compliance. Scotchmer (1989), emphasizing the informational aspects of third party assistance, suggests that if risk neutral taxpayers are not sure of their true taxable income, they will tend to overreport their tax liability because the cost of underreporting exceeds the cost of overreporting due to IRS penalties. In her models, taxpayers hire the services of informed third parties who reduce or eliminate uncertainty, and thereby lower the amount of reported tax liability.

Reinganum and Wilde (1991) analyze a game theoretic model of taxpayer, tax practitioner, and IRS behavior that focuses on the service aspects of third party assistance. They characterize four types of equilibria, depending on whether taxpayers prefer to use tax practitioners and whether the IRS prefers them to use tax practitioners. When tax practitioner penalties for noncompliance are sufficiently low and the efficiency gains from using practitioners are sufficiently high, the IRS prefers taxpayers to prepare their own returns, but taxpayers prefer to use a tax practitioner. In this case, the use of a tax practitioner is associated with lower compliance and higher audit rates.

Finally, Mazur and Nagin (1987), emphasizing the strategic aspects of third party assistance, observe that many paid preparers are "not just passive scribes whose function is limited to relieving their clients of the mechanical requirements of return preparation. To varying degrees they provide information on legal requirements and the penalties for their breach, develop strategies for reducing tax liability, provide counsel on the risks of executing such strategies and inform clients of topical enforcement priorities."

Most empirical analyses of the demand for third party assistance have estimated the effects of types of income, other return characteristics, and various socio-economic factors on the choice between self-preparation and all forms of third party assistance. Using a variety of data sources including surveys (Slemrod and Sorum, 1984; Collins, Milliron and Toy, 1988; Hite, 1987), 
TABle 1.-Number of Returns, Frequency, and Proportion of Noncompliance by Preparation Mode For $1979^{\mathrm{a}}$

\begin{tabular}{|c|c|c|c|}
\hline \multirow[b]{2}{*}{ Mode of Preparation } & \multicolumn{2}{|c|}{ Total Returns Filed } & \multirow{2}{*}{$\begin{array}{l}\text { Proportion of } \\
\text { Noncompliance }\end{array}$} \\
\hline & Number & Frequency & \\
\hline Self & 39959000 & 0.442 & 0.228 \\
\hline \multicolumn{4}{|l|}{ Non-Paid } \\
\hline IRS assisted ${ }^{b}$ & 1265686 - & 0.014 & 0.004 \\
\hline Other Non-Paid ${ }^{c}$ & 8317320 & 0.092 & 0.033 \\
\hline \multicolumn{4}{|l|}{ Paid Preparers } \\
\hline National Tax Service & 8588600 & 0.095 & 0.054 \\
\hline Local Tax Service & 10488000 & 0.116 & 0.132 \\
\hline Other Paid & 6690000 & 0.074 & 0.122 \\
\hline \multicolumn{4}{|l|}{ Practitioners } \\
\hline Public Accountant ${ }^{d}$ & 5605200 & 0.062 & 0.102 \\
\hline $\mathrm{CPA}^{\mathrm{e}}$ & 6057200 & 0.067 & 0.258 \\
\hline Attorney and CPA & 3435450 & 0.038 & 0.067 \\
\hline Total & 90406000 & 1.000 & 1.000 \\
\hline \multicolumn{4}{|c|}{$\begin{array}{l}\text { a Source: Special Academic Research File of the } 1979 \text { Individual Return TCMP. } \\
\text { The IRS Assistance category consists of three services. They are IRS Advice, with a population frequency of } \\
\text { 0.011; IRS Prepared, with a population frequency of 0.001; and IRS Reviewed, with a population frequency of } \\
0.004 \text {. } \\
\text { The other nonpaid category usually consists of a family member who helps prepare the return. We have } \\
\text { combined in this category all VITA prepared returns. VITA is an acronym for Volunteer Income Tax Assistance, } \\
\text { which consists of unpaid volunteers who prepare returns after receiving limited instruction, typically from the IRS. } \\
\text { d Public Accountants are licensed at the state level with requirements varying by state. Only four states, North } \\
\text { Carolina, Virginia, Kansas, and Wyoming do not regulate Public Accountants. National Tax Services, which in } \\
1979 \text { consisted entirely of H \& R Block and Beneficial Financial Services Co., and Local Tax Services often provide } \\
\text { their own training, but do not require employees to be Public Accountants. } \\
\text { e CPA is an abbreviation for Certified Public Accountant. }\end{array}$} \\
\hline
\end{tabular}

TCMP data (Dubin, Graetz, and Wilde, 1989; Erard, 1990), and the IRS Master File (Long and Caudill, 1987) researchers have found that the demand for third party assistance increases with amounts of total or complex income, age, return complexity, tax rates, the number of dependents, and self-employment, and decreases with the level of education.

A complete characterization of the impact of third parties on tax compliance would include analyses of taxpayer choices of the kind of third party assistance, the effect of third parties on tax compliance, and the IRS posture towards returns completed by third parties. We begin this expanded characterization by analyzing taxpayers' choices among 12 modes of third party assistance, using nested logit techniques applied to aggregate data from the Special Academic Research File of the 1979 Individual Return Taxpayer Compliance Measurement Program (TCMP). Although the best data on third party assistance released to date by the IRS, this data file limits the analysis to 696 aggregated observations from 12 IRS audit classes and 58 IRS districts. ${ }^{2}$

\footnotetext{
${ }^{2}$ For precise definitions of IRS audits classes as well as recent estimates of overall noncompliance see IRS (1990).
}

The paper is organized as follows. Section II presents an econometric specification of the demand for tax preparation services. Section III describes the data we use and models we estimate. Section IV presents our results and conclusions.

\section{A Model of Paid Preparer Selection}

We group types of return preparers according to natural patterns of substitutability. One group consists of CPAs, attorneys, and public accountants, which we label "practitioners," most of whom are licensed to represent taxpayers before the IRS. The second group consists of national tax services, local tax services, and other paid preparers who generally are not able to represent their clients before the IRS. The third group consists of third party assistors who are free of charge. A final group consists of self-preparers. We account for this pattern of substitutability in our estimation by using a two-stage nested multinomial logit model. ${ }^{3}$

First we estimate taxpayer choices among the four broad categories: practitioners, paid prepar-

\footnotetext{
${ }^{3}$ For a detailed discussion of the nested logit model see McFadden (1978).
} 
ers, nonpaid preparers, and self-preparation. Then we estimate taxpayers' choices between the modes of assistance within each category. ${ }^{4}$ Let $i=1, \ldots, I$ index the preparation category, and let $j=1,2, \ldots, J_{i}$ index the specific assistance modes within category $i$. We assume that the probability that an individual chooses alternative $i j, P_{i j}$, can be written as the product of the conditional probability $P_{j \mid i}$ and marginal probability $P_{i}$ with each probability in the multinomial logit form

$$
\begin{aligned}
& P_{j \mid i}=\frac{e^{\beta_{j \mid i}^{\prime} X}}{\sum_{j=1}^{J_{i}} e^{\beta_{j \mid i}^{\prime} X}} \\
& P_{i}=\frac{e^{\alpha_{i}^{\prime} Y+\theta_{i} I_{i}}}{\sum_{i=1}^{J_{i}} e^{\alpha_{i}^{\prime} Y+\theta_{i} I_{i}}} .
\end{aligned}
$$

Here $X$ and $Y$ are vectors of observed attributes which vary by audit class and IRS district and $I_{i}$ is the expected maximum utility (or inclusive value) a taxpayer derives from alternatives in the $i$ th category with

$$
I_{i}=\log \sum_{j=1}^{J_{i}} e^{\beta_{j \mid i}^{\prime} X} .
$$

The unknown parameters in this model are $\beta_{j \mid i}$, $\alpha_{i}$, and $\theta_{i}$ with the latter being a measure of the dissimilarity of alternatives in the $i$ th category. ${ }^{5}$

Since our data are aggregated to the IRS district level, we estimate $P_{j \mid i}$ and $P_{i}$ using an aggregate form of the nested logit model. ${ }^{6}$ Specifically, we form the log odds for equations (1) and (2) as

$$
\log \left[\frac{P_{j \mid i}}{P_{1 \mid i}}\right]=\beta_{j \mid i}^{\prime} X \quad \forall j \neq 1,
$$

and

$$
\log \left[\frac{P_{i}}{P_{1}}\right]=\alpha_{i}^{\prime} Y+\theta_{i}\left(I_{i}-I_{1}\right) \quad \forall i \neq 1 .
$$

${ }^{4}$ Alternative patterns of substitutability are considered by Udell (1991).

${ }^{5}$ McFadden (1978) proves that if $\theta_{i}$ lies in the closed interval $[0,1]$ the resultant nested logit is consistent with random utility maximization.

${ }^{6}$ The estimation of nested logit models has to date relied exclusively on individual level data. We extend the nested logit method for use with aggregate data following Berkson (1944) and Theil (1969). Implicit in this development is the assumption of homogeneity of individuals within the aggregation classes. For a discussion of the robustness properties of logit techniques when applied to aggregate data, see also Allenby and Rossi (1991).
Estimation of equations (4) and (5) requires estimates of the choice probabilities for which we use the observed selection frequencies and measures of $X$ and $Y$ for which we use group weighted averages. Denote the probability that an individual in the $k$ th IRS district chooses alternative ij as $P_{i j}^{k}$. Let the number of cases in the $k$ th IRS district be $N^{k}$ and denote the frequency of occurrences of alternative $i j$ in district $k$ as $F_{i j}^{k}$. Suppressing the superscript $k$ we can write

$$
\log \left[\frac{F_{j \mid i}}{F_{1 \mid i}^{\prime}}\right]=\beta_{j \mid i}^{\prime} X+\mu_{j \mid i},
$$

and

$$
\log \left[\frac{F_{i}}{F_{1}}\right]=\alpha_{i}^{\prime} Y+\theta_{i}\left(I_{i}-I_{1}\right)+\mu_{i},
$$

with

$$
\mu_{j \mid i}=\log \left[\frac{F_{j \mid i}}{F_{1 \mid i}}\right]-\log \left[\frac{P_{j \mid i}}{P_{1 \mid i}}\right]
$$

and

$$
\mu_{i}=\log \left[\frac{F_{i}}{F_{1}}\right]-\log \left[\frac{P_{i}}{P_{1}}\right]{ }^{7}
$$

Straightforward calculations show that

$$
\begin{aligned}
& E\left(\mu_{j \mid i}\right)=0 \\
& V\left(\mu_{j \mid i}\right)=\frac{1}{N}\left(\frac{1}{P_{j \mid i}}+\frac{1}{P_{1 \mid i}}\right) \text { for } j \neq 1, \\
& \operatorname{cov}\left(\mu_{j \mid i}, \mu_{1 \mid i}\right)=\frac{1}{N P_{1 \mid i}} \text { for } j \neq 1,
\end{aligned}
$$

and that

$$
\begin{aligned}
& E\left(\mu_{i}\right)=0, \\
& V\left(\mu_{i}\right)=\frac{1}{N}\left(\frac{1}{P_{j}}+\frac{1}{P_{1}}\right) \quad \text { for } j \neq 1, \\
& \operatorname{cov}\left(\mu_{j}, \mu_{1}\right)=\frac{1}{N P_{1}} \text { for } j \neq 1 .
\end{aligned}
$$

Since $P_{i j}$ varies with the alternative and $N$ varies with the size of each audit class and IRS district, equations (8) and (10) present a classic form of

\footnotetext{
${ }^{7}$ Our data set has an average of 70 individuals per cell. Monte Carlo evidence reported in Domencich and McFadden (1975) shows that when cell sizes are large (over 30 observations) the Berkson-Theil estimator of equations (6) and (7) has very small sample bias (see table 5.1, p. 113).
} 
heteroscedasticity. Furthermore, a nonzero covariance is also present (equations (9) and (11)) since the log odds equations (6) and (7) use common comparison groups. Minimum chi-square estimation of the nested logit model corrects simultaneously for this covariance structure.

\section{Model Specification}

The TCMP program involves line-by-line audits of approximately 50,000 randomly chosen individual tax returns. Our data file aggregates the results of the 1979 TCMP audits by IRS district and audit class. Six audit classes comprise returns where income was not derived principally from farm or sole-proprietorship activities, three others where income was derived principally from sole-proprietorships, and a final three where income was derived principally from farm activities. For every line for each audit class in each of the districts, taxpayers' reported amounts are recorded as well as the adjusted amounts recommended by the TCMP audit. For the 1979 TCMP, additional information was recorded on the 12 return preparation modes used by taxpayers. To avoid districts with too few observations, we combine all attorneys into a single category and assign the following mnemonics to the resulting practitioner alternatives:

PA $=$ Public Accountant

ATT $=$ Attorney, or Attorney and CPA

CPA $=$ Certified Public Accountant.

The three paid-preparer alternatives are

LTS $=$ Local Tax Service

OPP $=$ Other Paid Preparer

NTS $=$ National Tax Service.

Finally, we combine several nonpaid assistance alternatives and assign the following mnemonics:

$$
\begin{aligned}
\text { IRS }= & \text { IRS prepared, IRS reviewed, } \\
& \text { or IRS assisted } \\
\text { ONP }= & \text { Volunteer Income Tax Assistance }, \\
& \text { or Other Nonpaid Preparers } \\
\text { SELF }= & \text { Self-prepared. }
\end{aligned}
$$

As discussed in the Introduction, three basic motives for taxpayers to use third party assistance have been identified; information (Scotchmer); service (Reinganum and Wilde); and strategic (Mazur and Nagin). Our choice of explanatory variables parallels these motives. In particular, we assume that the probability of choosing any mode of third party assistance or self-preparation is a function of the IRS audit rate (AUDIT), the frequency of penalties (PENALTY), the percentage of the adult population with a high school education (EDUCATE), the percentage of the adult population over 65 years old ( $A G E 65$ ), state, local, and real-estate tax deductions (TAXDED), other deductions (OTHDED), the number of exemptions (EXEMPT), the sum of wage, interest, and dividend income (SIMPLE), the sum of schedule $\mathrm{C}$ gross receipts and partnership income (BUSINESS), other income (OTHINC), and the number of forms included with the taxpayer's return (FORMS).

Although we make no attempt to test one against another, our predictions regarding the effects of the explanatory variables on the demand for third party assistance are based on the service, information, and strategic motives. We next summarize our general expectations regarding the effects of the explanatory variables on the demand for third party assistance with occasional reference to specific motives.

Since neither nonpaid nor paid preparers generally can represent clients before the IRS, increases in the IRS enforcement activity variables RATE or PENALTY should increase the demand for practitioners. ${ }^{8}$ Because more educated taxpayers are better able to prepare their own returns, represent themselves before the IRS, determine their own true tax liability, and engage in appropriately strategic behavior, increases in EDUCATE should reduce the demand for all modes of third party assistance and increase selfpreparation. An increase in $A G E 65$ may possibly increase the demand for preparers and practitioners based on the service and information motives. ${ }^{9}$

Our tax return variables reflect the TCMP adjusted levels for three basic components of the tax calculation: income, deductions, and exemptions. ${ }^{10}$ We use three measures of income; the sum of wages, interest, and dividends, the sum of schedule $\mathrm{C}$ gross receipts and partnership in-

\footnotetext{
${ }^{8}$ The audit rate is based on audits accomplished data provided by the Examination Division of the IRS. The frequency of penalties is obtained directly from the aggregated TCMP data file.

${ }^{9}$ The percentage of the adult population with a high school education and the percentage of the adult population over age 65 are from the Statistical Abstract of the United States for the year 1979 .
} 
Figure 1.-Choice of Tax Return Preparation Services

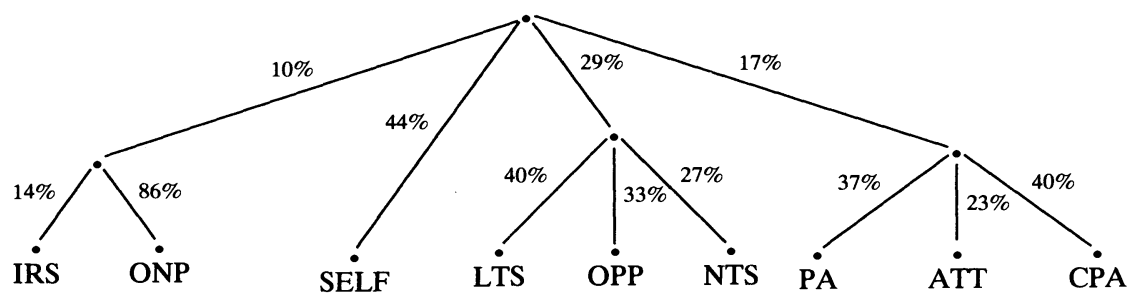

come, and all other income. Increases in SIMPLE should decrease the demand for third party assistance and increase self-preparation, since for taxpayers with predominately wage, interest, or dividend income, there is less need for service or information, less opportunity for strategic behavior and little likelihood of IRS enforcement attention. Increases in BUSINESS should increase the demand for practitioners since owners of small businesses do face substantial IRS enforcement attention, considerable complexity, and may as a normal business practice require the services of attorneys or highly qualified accountants. We have no a priori expectations with respect to the effect of increases in OTHINC on the demand for third party assistance and selfpreparation, but include it in our specification in order to account for all income.

We divide deductions into state, local, and real estate taxes and other deductions. Since taxpayers who pay state and local taxes may be subject to state enforcement attention as well as IRS enforcement attention, increases in TAXDED may increase the demand for practitioners. ${ }^{11} \mathrm{Un}$ like state, local, and real estate taxes which are not likely to be contested, other deductions often are contested. This suggests that increases in $O T H D E D$ should also increase the demand for practitioners. By our definition, EXEMPT primarily measures family size. To the extent that

\footnotetext{
${ }^{10}$ The TCMP provides not only what the tax return reported amounts were, but what the IRS believed the true amount to be. We use the corrected amounts of deductions and exemptions as meaningful measures of the true amounts of these items.

${ }^{11}$ See Dubin, Graetz, and Wilde (1989) for a discussion of the relationship between state and federal enforcement activity.
}

larger families have greater demand for tax services, an increase in EXEMPT should increase the demand for both preparers and practitioners. $^{12}$ Finally, the number of forms is a straightforward measure of return complexity and as such increases in FORMS should increase the demand for both preparers and practitioners.

\section{Results and Conclusions}

The choice of third party assistance is estimated in two stages, as discussed in section II and illustrated in figure 1 . Table 2 presents the elasticities of the unconditional choice probabilities $P_{i j}$ with respect to the underlying explanatory variables. ${ }^{13}$

Our results generally are consistent with our expectations. Increases in the IRS audit rate or frequency of penalties increase significantly the demand for practitioners. For the audit rate this effect is limited to CPAs, but for the frequency of penalties the effect applies to all three types of practitioners. For the audit rate, this increase comes at the expense of national tax services while for the frequency of penalties it comes largely at the expense of self-preparation.

\footnotetext{
${ }^{12}$ We subtract exemptions for over 65 years of age and blindness from total exemptions. The remainder is a measure of the number of persons supported by the taxpayer.

${ }^{13}$ These elasticities are based on sequential estimation of the nested logit model, which includes the estimation of the dissimilarity parameters as discussed in section II. These parameters are $0.28,0.85$, and 1.4 for nonpaid preparers, paid preparers, and practitioners, respectively. The last of these is not significantly different from 1 . The calculation of the elasticities is complicated by the fact that each explanatory variable has a distinct affect on all alternatives at each level of the nested logit tree. The mean values of all variables and a discussion of their units is available on request. Further details concerning the data base, the estimation method and calculation of the elasticities are available in Udell (1991).
} 
Table 2.-Response Elasticities of Explanatory Variables by Mode of Preparation

\begin{tabular}{|c|c|c|c|c|c|}
\hline \multirow[b]{2}{*}{ Mode } & \multicolumn{2}{|c|}{ Nonpaid Preparers } & \multicolumn{3}{|c|}{ Paid Preparers } \\
\hline & IRS & ONP & LTS & OP & NTS \\
\hline CONSTANT & $\begin{array}{c}0.695 \\
(0.845)\end{array}$ & $\begin{array}{c}4.625 \\
(8.468)\end{array}$ & $\begin{array}{c}-1.742 \\
(-2.290)\end{array}$ & $\begin{array}{c}-0.762 \\
(-0.967)\end{array}$ & $\begin{array}{c}-1.640 \\
(-2.098)\end{array}$ \\
\hline$R A T E$ & $\begin{array}{c}-0.573 \\
(-1.899)\end{array}$ & $\begin{array}{c}0.266 \\
(1.331)\end{array}$ & $\begin{array}{c}0.254 \\
(0.724)\end{array}$ & $\begin{array}{c}-0.214 \\
(-0.600)\end{array}$ & $\begin{array}{c}-0.787 \\
(-2.209)\end{array}$ \\
\hline PENALTY & $\begin{array}{c}-0.187 \\
(-0.836)\end{array}$ & $\begin{array}{c}0.040 \\
(0.333)\end{array}$ & $\begin{array}{c}-0.005 \\
(-0.100)\end{array}$ & $\begin{array}{c}0.136 \\
(1.875)\end{array}$ & $\begin{array}{c}0.054 \\
(0.769)\end{array}$ \\
\hline EDUCATE & $\begin{array}{c}-0.840 \\
(-1.439)\end{array}$ & $\begin{array}{c}-3.119 \\
(-8.611)\end{array}$ & $\begin{array}{c}0.484 \\
(1.192)\end{array}$ & $\begin{array}{c}-0.051 \\
(-0.118)\end{array}$ & $\begin{array}{l}1.123 \\
(2.631)\end{array}$ \\
\hline$A G E 65$ & $\begin{array}{c}0.081 \\
(0.293)\end{array}$ & $\begin{array}{c}-0.542 \\
(-3.098)\end{array}$ & $\begin{array}{c}-0.205 \\
(-1.545)\end{array}$ & $\begin{array}{c}-0.584 \\
(-3.442)\end{array}$ & $\begin{array}{c}-0.267 \\
(-1.757)\end{array}$ \\
\hline$T A X D E D$ & $\begin{array}{c}0.108 \\
(0.560)\end{array}$ & $\begin{array}{c}0.039 \\
(0.400)\end{array}$ & $\begin{array}{c}-0.175 \\
(-2.707)\end{array}$ & $\begin{array}{c}0.073 \\
(1.061)\end{array}$ & $\begin{array}{c}-0.196 \\
(-2.707)\end{array}$ \\
\hline OTHDED & $\begin{array}{c}-0.355 \\
(-1.575)\end{array}$ & $\begin{array}{c}-0.007 \\
(-0.062)\end{array}$ & $\begin{array}{c}0.206 \\
(2.758)\end{array}$ & $\begin{array}{c}-0.169 \\
(-2.038)\end{array}$ & $\begin{array}{c}-0.065 \\
(-0.791)\end{array}$ \\
\hline$E X E M P T$ & $\begin{array}{c}-0.968 \\
(-2.257)\end{array}$ & $\begin{array}{c}-1.587 \\
(-6.650)\end{array}$ & $\begin{array}{c}1.087 \\
(6.308)\end{array}$ & $\begin{array}{c}1.240 \\
(6.382)\end{array}$ & $\begin{array}{c}1.345 \\
(6.925)\end{array}$ \\
\hline SIMPLE & $\begin{array}{l}-0.108 \\
(-0.552)\end{array}$ & $\begin{array}{l}-0.362 \\
(-3.155)\end{array}$ & $\begin{array}{c}-0.240 \\
(-3.964)\end{array}$ & $\begin{array}{c}-0.317 \\
(-4.352)\end{array}$ & $\begin{array}{c}-0.280 \\
(-3.919)\end{array}$ \\
\hline BUSINESS & $\begin{array}{c}-0.077 \\
(-0.220)\end{array}$ & $\begin{array}{c}-0.249 \\
(-0.721)\end{array}$ & $\begin{array}{c}0.012 \\
(0.257)\end{array}$ & $\begin{array}{c}0.016 \\
(0.332)\end{array}$ & $\begin{array}{c}0.027 \\
(0.518)\end{array}$ \\
\hline OTHINC & $\begin{array}{c}0.069 \\
(0.343)\end{array}$ & $\begin{array}{c}-0.108 \\
(-0.658)\end{array}$ & $\begin{array}{c}-0.056 \\
(-1.008)\end{array}$ & $\begin{array}{c}-0.053 \\
(-0.882)\end{array}$ & $\begin{array}{c}0.003 \\
(0.054)\end{array}$ \\
\hline FORMS & $\begin{array}{c}-0.048 \\
(-0.075)\end{array}$ & $\begin{array}{c}0.301 \\
(0.904)\end{array}$ & $\begin{array}{c}0.481 \\
(2.609)\end{array}$ & $\begin{array}{r}0.237 \\
(1.152)\end{array}$ & $\begin{array}{c}0.083 \\
(0.399)\end{array}$ \\
\hline & \multicolumn{4}{|c|}{ Practitioners } & Self-prepared \\
\hline Mode & PA & ATT & & & Self \\
\hline ONSTA & $\begin{array}{c}-3.810 \\
(-4.830)\end{array}$ & $\begin{array}{c}-5.583 \\
(-6.745)\end{array}$ & & & $\begin{array}{c}1.751 \\
(4.730)\end{array}$ \\
\hline$R A T E$ & $\begin{array}{c}0.228 \\
(1.176)\end{array}$ & $\begin{array}{c}0.160 \\
(0.788)\end{array}$ & & & $\begin{array}{c}-0.015 \\
(-0.111)\end{array}$ \\
\hline PENALTY & $\begin{array}{c}0.363 \\
(5.535)\end{array}$ & $\begin{array}{c}0.244 \\
(2.992)\end{array}$ & & & $\begin{array}{c}-0.182 \\
(-5.869)\end{array}$ \\
\hline EDUCATE & $\begin{array}{c}-0.163 \\
(-0.460)\end{array}$ & $\begin{array}{c}0.647 \\
(1.586)\end{array}$ & & & $\begin{array}{c}0.274 \\
(1.659)\end{array}$ \\
\hline$A G E 65$ & $\begin{array}{c}0.722 \\
(4.301)\end{array}$ & $\begin{array}{c}0.887 \\
(4.410)\end{array}$ & & $\begin{array}{l}31 \\
42)\end{array}$ & $\begin{array}{c}0.081 \\
(1.416)\end{array}$ \\
\hline$T A X D E D$ & $\begin{array}{c}0.180 \\
(4.883)\end{array}$ & $\begin{array}{c}0.195 \\
(5.124)\end{array}$ & & & $\begin{array}{l}-0.005 \\
(-0.209)\end{array}$ \\
\hline OTHDED & $\begin{array}{c}-0.34 \\
(-0.483)\end{array}$ & $\begin{array}{c}0.198 \\
(2.679)\end{array}$ & & & $\begin{array}{c}-0.068 \\
(-2.471)\end{array}$ \\
\hline$E X E M P T$ & $\begin{array}{c}1.445 \\
(7.583)\end{array}$ & $\begin{array}{c}1.249 \\
(5.654)\end{array}$ & & & $\begin{array}{c}-0.937 \\
(-12.680)\end{array}$ \\
\hline SIMPLE & $\begin{array}{l}-0.267 \\
(-4.229)\end{array}$ & $\begin{array}{c}-0.371 \\
(-5.366)\end{array}$ & & $\begin{array}{l}79 \\
46)\end{array}$ & $\begin{array}{c}0.345 \\
(12.397)\end{array}$ \\
\hline BUSINESS & $\begin{array}{c}0.085 \\
(1.861)\end{array}$ & $\begin{array}{c}0.068 \\
(1.395)\end{array}$ & & & $\begin{array}{c}-0.001 \\
(-0.003)\end{array}$ \\
\hline OTHINC & $\begin{array}{c}-0.029 \\
(-0.588)\end{array}$ & $\begin{array}{c}-0.021 \\
(-0.378)\end{array}$ & & & $\begin{array}{c}0.049 \\
(1.303)\end{array}$ \\
\hline FORMS & $\begin{array}{c}0.611 \\
(3.952)\end{array}$ & $\begin{array}{c}1.342 \\
(7.944)\end{array}$ & & & $\begin{array}{c}-0.624 \\
(-6.526)\end{array}$ \\
\hline
\end{tabular}

Note: $t$-statistics are in parentheses. 
As predicted, an increase in the percentage of the adult population with a high school education increases self-preparation. However, it does not decrease the demand for all forms of third party assistance. In particular, other nonpaid preparer shows a statistically significant fall in demand, and the demand for national tax services actually shows a significant increase. An increase in the percentage of the adult population over age 65 increases the demand for practitioners and decreases the demand for paid preparers.

Some of our strongest results are obtained with respect to tax return variables. Increases in wages, interest, and dividends significantly decrease the demand for all forms of third party assistance except IRS assistance, and very significantly increase self-preparation. Increases in schedule C gross receipts and partnership income, as expected, increase the demand for practitioners and have no significant effect on any other particular mode of preparation including self-preparation. Finally, an increase in other income, perhaps surprisingly, has no statistically significant effect on any form of third party assistance or self-preparations.

With respect to deductions, an increase in state, local, or real estate taxes significantly increases the demand for practitioners. However, it actually decreases the demand for local and national tax services, an effect which we did not expect. Among all the explanatory variables, the number of exemptions has the strongest effects; increases in it significantly decrease self-preparation and increase the demand for all forms of paid third party assistance. It also significantly decreases the demand for nonpaid preparers. Finally, the number of forms also has a pattern of effects consistent with our expectations; increases in the number of forms increase the demand for practitioners, decrease self-preparation, and have little effect on the demand for other modes of third party assistance.

These results generally confirm the results obtained by other investigators. However, in many cases we find significant differences between the effect of explanatory variables on paid-preparers as compared to practitioners. In particular, many of the results obtained in previous studies which differentiate only between self-preparation and all forms of third party assistance seem to be driven by the demand for practitioners. We also have obtained new results regarding the effect of audit rates and the frequency of penalties on the demand for third party assistance. These results will be particularly important when we turn to the effects of third party assistance on noncompliance. Nevertheless some of our results must be viewed as preliminary. In particular, while our results with respect to the percentage of the adult population over 65 and the number of exemptions conform to our expectations, better data and further investigations are needed fully to understand the relationship between these variables and the demand for third party assistance.

Even at this early stage, we can, however, speculate on the change in noncompliance induced by a shift in return preparation. For example, consider a change in information reporting which has the effect of increasing the amount of simple income relative to other forms of income. In this case, we would predict an increase in self-preparation. If the level of noncompliance attributable to self-prepared returns does not change, then a net reduction in noncompliance would result. However, since the choice of a type of tax return preparation may itself be conditioned on the level of tax evasion, consistent determination of the levels of noncompliance attributable to specific preparer types must take account of the potential for self-selection bias.

\section{REFERENCES}

Allenby, Greg, and Peter Rossi, "There Is No Aggregation Bias: Why Macro Logit Models Work," Journal of Business and Economic Statistics 9 (Jan. 1991), 1-14.

Berkson, Joseph, "Application of the Logistic Function to Bio-Assay," Journal of the American Statistical Association 39 (Sept. 1944), 357-365.

Collins, Julie, Valerie Milliron, and Daniel Toy, "Tax Preparer Usage and Its Implications," mimeographed, University of North Carolina, 1988.

Domencich, Thomas, and Daniel McFadden, Urban Travel Demands. (New York: North-Holland Publishing Co., 1975).

Dubin, Jeffrey, Michael Graetz, and Louis Wilde, "The Report of the United States to the International Fiscal. Association on the Administrative and Compliance Costs of Taxation," in Cahiers of the International Fiscal Association 43 Congress (Netherlands: Kluwer, 1989), 311-344.

Erard, Brian, "An Endogenous Switching Analysis of Preparation Mode and Tax Compliance," mimeographed (Ann Arbor: University of Michigan, 1990).

Hite, Peggy, "Characteristics of Taxpayers Who Use Preparers: An Exploratory Study," paper prepared for IRS Research Conference on The Role of Tax Practitioners in the Tax System (Washington, D.C., November 16-17, 1987). 
Internal Revenue Service, Net Tax Gap and Remittance Tax Gap Estimates, Publication 1415 (Washington, D.C.: Research Division, Compliance Estimates Group, April 1990).

Long, James, and Steven Caudill, "The Usage and Benefits of Paid Tax Return Preparation," National Tax Journal 40 (Mar. 1987), 35-46.

McFadden, Daniel, "Modeling the Choice of Residential Location," in A. Karlquist et al. (ed.), Spatial Interaction Theory and Planning Models (Amsterdam: North-Holland Publishing, 1978).

Mazur, Mark, and Daniel Nagin, "Tax Preparers and Tax Compliance: A Theoretical and Empirical Analysis," mimeographed, Carnegie-Mellon University (Nov. 1987).
Reinganum, Jennifer, and Louis Wilde, "Equilibrium Enforcement and Compliance in the Presence of Tax Practitioners," Journal of Law, Economics, and Organization 7 (Spring 1991), 163-181.

Scotchmer, Suzanne, "Who Profits from Taxpayer Confusion?" Economics Letters 29 (1) (1989), 49-55.

Slemrod, Joel, and Nikki Sorum, "The Compliance Cost of the U.S. Individual Income Tax System," National Tax Journal 37 (Dec. 1984), 461-474.

Theil, Henri, "A Multinomial Extension of the Linear Logit Model," International Economic Review 10 (Oct. 1969), 251-259.

Udell, Michael, "The Effects of Tax Preparers on Tax Compliance," unpublished Ph.D. dissertation, California Institute of Technology, 1991. 